\title{
Unemployment News and Stock Market Returns: A Study on OECD Countries
}

\author{
Asst. Prof. Dr. Ensar Ağırman (Atatürk University, Turkey) \\ Prof. Dr. Reşat Karcıoğlu (Atatürk University, Turkey) \\ Ph.D. Candidate Asfia Binte Osman (Atatürk University, Turkey)
}

\begin{abstract}
Unemployment is one of the major macroeconomic factors which has always been a big issue for an economy as it has a direct influence on living condition of citizens and is helpful in ensuring a sound and growing economic system. Based on logical concept it can be said that employment rate states the financial soundness of citizens, specifies their spending capacities, saving and investment behavior in real and financial assets; thus, related to stock market activities.

Researchers decided to conduct the study on unemployment; only a factor of macro economy considering its significance in research area that has been started with a good number of studies done by different researchers based on different countries on different periods, but this study is different from previous studies from some point of views: 1) It will cover a huge number of countries with several economic classes; 2) This study will represent the relationship between unemployment and stock market returns of the countries under a single study which are significant from world perspective because of having power to influence the activities of other countries; 3) This study will help researchers, policy makers and learners to get a clear idea about the interrelationship among these two components over a wide range of countries together. The study will conduct on all the member countries ( 35 countries) of OECD and will use Panel Data analysis for the period of $2008-2017$.
\end{abstract}

\section{Introduction}

The various economic activities of a country influence stock market returns (Liu and Shrestha, 2008). For this reason, many studies have been conducted to examine the relationship between stock market and macroeconomic factors. Those studies witness the existence of relationship between stock market and macroeconomic factors. Unemployment is one of the major macroeconomic factors. It has always been a big issue for an economy as it has a direct influence on living condition of citizens and is helpful in ensuring a sound and growing economic system. Based on logical concept it can be said that employment rate states the financial soundness of citizens, specifies their spending capacities, saving and investment behavior in real and financial assets; thus, related to stock market activities. Besides institutional investors, only employed persons can contribute to invest in stock market freely and can influence stock prices through creating demand for shares of companies as the scope to invest money in stock market is comparatively narrower for unemployed people if no other exception occurs. Moreover, an employed person can spend money in buying products of companies, helps to increase productivity of companies, increase in demand for funds for companies and high demand for funds results in high stock returns and stock prices. From this viewpoint the existence of interrelationship between stock market and unemployment is certain/easily understandable, but it is also important to measure the relationship between employment rate and stock returns statistically. As we know some factors affect economic activity strongly but some are not. Therefore, unemployment factor may have significant impact on some economies but little or no in other economies which we can also witness with the results of previous studies that had been done on different countries. Review of literatures done by researchers also reveal that in some countries unemployment has significant impact but, in some countries, it has insignificant impact on stock market returns.

Huge number of organizations are working world wide to boost up economic condition of the member countries or all the countries of the world through co- operating each other with providing necessary help and support. OECD is one of them which was formed to motivate economic progress and trade all over the world, working towards the achievement of their goals with different policies and strategies. Countries with different economic classes have come under one umbrella through its formation to ensure combined economic progress throughout the world. This study has been conducted on OECD countries considering three objectives to be served together. They are:

1) A large number of countries will come under consideration to be studied together;

2) Results will show the relationship status between two integral factors of countries with different economic classes;

3) Would be able to see the impact of unemployment on stock returns of the countries aiming to ensure economic progress worldwide regardless of concentrating on themselves individually.

With an extensive review of literature is has been found that a bulk of studies have been conducted before considering a number of macro-economic variables together like- money supply, interest rate, industrial production, unemployment, inflation, exchange rate etc. Researchers decided to conduct the study on unemployment; only a factor of macro economy considering its significance in research area that has been started 
with a good number of studies done by different researchers based on different countries on different periods, but this study is different from previous studies from some point of views: 1) It will cover a huge number of countries with several economic classes; 2) This study will represent the relationship between unemployment and stock market returns of the countries under a single study which are significant from world perspective because of having power to influence the activities of other countries; 3 ) This study will help researchers, policy makers and learners to get a clear idea about the interrelationship among these two components over a wide range of countries together. The study has been conducted on all the member countries (35 countries) of OECD and finds that unemployment is no the granger cause of Stock Market. There is unidirectional causality between variables. In the long run, the stock market is the determinant of unemployment but not vice versa.

Remaining parts of the paper includes a brief discussion on concepts related to study in section 2, Review of previous literatures in section 3, methodology in section 4, analysis, findings and recommendations have been structured in section 5. A conclusion has been drawn in section 6 providing a brief of the total study, followed by the limitation(s) of the study and future research guideline.

\subsection{Conceptual Details of Related Key Components}

Generally, unemployment denotes the situation when despite of having sufficient labor force in the economy if there is lack of work opportunities for them. The U.S. Bureau of Labor Statistics defines a person as unemployed if they are not working but are willing and able to work. More precisely, unemployment is when the labor force is seeking employment but cannot find it. After having a good idea about unemployment, it is important to know about unemployment rate and formula to calculate it.

The unemployment rate is the percentage of the labor force that is unemployed. General formula to calculate unemployment rate is:

$$
\text { Unemployment Rate }=\frac{\text { Number of unemployed persons }}{\text { Labor force }}
$$

Employment rate or unemployment rate is considered as one of the factors that influence economy; more or less; directly or indirectly. Another factor that contributes to economic development of every country is Stock Market. It is a mechanism through which funds are transferred from surplus unit to deficit unit of the economy through a buying and selling process among the participating parties. It basically exists to perform several functions to contribute to economic expansion of a country like- working as an economic barometer to read the prevailing economic condition of the country, helping to determine the value of securities, ensuring a safe way of transaction between buyers and sellers, contributing to economic growth, promoting saving and investment, helping companies in raising funds, helping to allocate fund in a better way; last but not the least, providing a platform to liquidate fund easily and quickly.

In every country along with internal components (Stock market, Macro-micro economic factors, and National institutions) there exist external components (foreign aids, loans, support of different international organizations) that also contribute to ensure economic development of that particular country. Different organizations play a pivotal role in this regard. OECD holds significant position in this aspect as it performs multifarious activities to ensure economic development and promotion of business activities worldwide. Its major functions includes-: helping governments of member countries in solving universal problems, organizing policies and comparing their policy experiences, monitoring economic trends including trade, technology, environment, taxation and agriculture, providing statistics intellectual findings, offering peer reviews to member countries and offering helps through expertise and ideas to more than 100 non-member countries to improve their economic conditions. Therefore, functions of the OECD clearly declare its long term commitment and contribution for overall economic development of countries all over the world, also is continuously working to achieve its goal in more innovative way, with more appropriate policies and strategies.

\section{Literature Review}

Stock market plays a significant role in forming and strengthening the economic infrastructure of an economy. It is an instrument through which seekers of funds and providers of fund meet together and ensure reciprocal benefits among themselves as well as work together in ensuring economic soundness of the respective countries. Stock market, being the most significant source of funds in boosting up industrial growth is subject to performance risk because of the presence of some macroeconomic variables prevails in an economy. So, it has always been a matter of concern to the researchers that whether these macro-economic variables have any relationship with stock market, if it has, to what extent and/ or what kind of. A huge number of researches have been made on this topic coving different countries of the world. Countries belong to higher income group are USA, UK, Japan, China, Taiwan etc. (World Bank data, 2018). Studies in some of these countries reveals different sets of results. Such for example: In Japan, Mukherjee and Naka (1995) found that exchange rate, money-supply, industrial production, call money rates have positive relation, but inflation, long term government bond rates have negative relation with TSE. Liu and Shrestha (2008) mentioned that in China IP and MS are positively but inflation, interest rate and 
currency value are negatively related to stock prices. Singh, T. et al. (2011) showed a negative relationship between selected macroeconomic variables (inflation rate, exchange rate, money supply) and stock returns in Taiwan.

Along with developed countries, a number of studies have been conducted on upper and lower middle countries too. Study of Şerife, Ö. \& Ugur, E. (2012) found that GDP and exchange rate have great impact on portfolios of companies in Turkey. Kotha, K.K. \& Sahu, B. (2016) discloses the presence of long run relation between the BSE Sensex and select macroeconomic indicators viz., Exchange Rate, wholesale price index, T-bill rates and M3 in their study in India. Pal \& Mittal (2011) \& Gunasekarage et al. (2004) also showed a significant relationship between macroeconomic variables and stock returns, but a different outcome has been observed in the study of Tangjitprom (2011) who found insignificant relationship between Interest rate, exchange rate and stock returns in his study on Thailand.

Tangjitprom (2011) cited unemployment rate as a factor that represents general business condition and business cycle of a country. Chen et al., (1986) suggested a number of factors in their study that can be analyzed while observing stock returns, unemployment rate is one of them. It clearly states the significance of this factor to be studied with to learn the impact of macroeconomic factors on stock market.

Previous literature reveals that a number of studies have been done coving unemployment as one of the important factors of macro economy. Different results came into existence. For instance, Gonzalo,J \& Taamout,A (2017) investigated the short-run impact of anticipated and unanticipated unemployment rates on stock prices in USA during 1950-2014. Using nonparametric Granger causality and quantile regression analysis, concluded that only anticipated unemployment rate has a strong impact on stock prices and considered unemployment rate as a good news for stock prices. Brooks and Tsolacos (1999) in their study also confirmed the existence of significant relationship between some macroeconomic factors including unemployment and property returns in UK in their study during 1985-1998. Chen et al. (2005) investigated the relationship between macro and non-macroeconomic factors and the hotel stock returns on the Taiwan stock exchange for the period of 1989-2003. With regression analysis they showed that among all the macro-economic factors merely money supply and the unemployment rate significantly explained the movement of hotel stock returns. On the other hand, Francisco J. \& Loredana N. (2016) conducted a research study on US stock market during 2008-2014 where researchers applied Dow Jones and S\&P500 indices to analyze the relationship between the US stock market and some relevant US macroeconomic factors and found that despite of having positive significant result with other factors unemployment rate and interest rate have negative and statistically significant relationships with the stock market. Aktas (2011) studied the influence of 19 macroeconomic announcements on equity index options for the period from 1983 to 2002 on Istanbul Stock Exchange (ISE) and found out that balance of trade, consumer price index, producer price index, employment, housing starts, money supply and retail sales are strongly related with index option returns.

Besides these studies, there are some studies that provided with different results in respect of the relationship between unemployment and stock returns. Farsio, F. \& Fazel,S.(2013) conducted a research covering three economically significant countries of the world. Researchers investigated the relationship between unemployment rate and stock prices in USA, China and Japan during 1970-2011. With Co-integration and Granger Causality tests they reached at the decision that it would be a mistake to rely on unemployment rate data to make investment decisions in the stock market. They also succeed to show that there is no stable long term relationship between unemployment and stock prices.

Singh,T. et al.(2011) and Şerife, Ö. \& Ugur. E. (2012) and Tangjitprom (2011) also found that unemployment doesn't have any significant influence on stock returns in Taiwan, Turkey and Thailand respectively. Tapa N. et al. (2016) in their study during 1994-2016 on South Africa also rejects the idea of unemployment being a good predictor for stock market returns. Also exhibits that developments in the stock market have no effect on the unemployment rate.

The way macroeconomic factors effecting an economy somehow depends on the state of economy. Orphanides (1992) mentioned that stock price response to macroeconomic news depends on state of economy. Blanchard (1981) has mentioned in his study that in equilibrium the same news can sometimes be good and sometimes be bad for financial assets, depending on the economic condition of an economy, i.e. Expansion or contraction state of economy. John H. B. et al . (2002), Boyd et al. (2005) and McQueen and Roley (1993) also run a research on US economy. They looked at the impact of unemployment on stock prices and specified that rising unemployment has a negative impact on stock prices during contractions but has a positive impact during expansion in the economy. Researches statements are evidence on the issue that whether macroeconomic factors bring good or bad news for stock market it depends on economic condition of a particular country. Whether is blessing during economic expansion can be proved as curse during economic contractions.

Being motivated by the previous studies showing the relationship between unemployment and stock returns covering different aspects, researchers have also conducted this study to measure the relationship between them but their study covered OECD countries which made their study unlike from others as no studies have been done previously covering all those countries together. 


\section{Methods}

The question of whether to detrend or to difference a time series prior to further analysis depends on whether the time series is TSP (trend-stationary process) or DSP (difference-stationary process).

A time series is said to have a unit root if we can write it as

$\mathrm{Yt}=\mathrm{DTt}+\mathrm{ut}$

ut $=\varphi \mathrm{ut}-1+\varepsilon \mathrm{t}$

with $\varphi=1$, et stationary and DTt a deterministic component.

ut is stationary and Yt is stationary around the change in the

deterministic part. In this case $\mathrm{Yt} \sim \mathrm{I}(1)$.

At the last stage of the analyses we use Dumitrescu-Hurlin (2012) panel causality test to determine causality relationship between variables. It is also possible utilize from test when $\mathrm{T}>\mathrm{N}$ or $\mathrm{T}<\mathrm{N}$ situations. Another advantage of test is it considers cross section dependence and provides efficient result even in cases where we have unbalanced panel data. Dumitrescu-Hurlin (2012) test proposes Homogeneous Non Causality (HNC) hypothesis by taking into account both the heterogeneity of the regression model and that of the causal relation. Under the alternative hypothesis it is allowed for a subgroup of individuals for which there is no causality relation and a subgroup of individuals for which the variable x Granger causes y. so the null hypothesis of HNC is defined as:

In this equation $\beta i$ continues as . It can be change across groups. Test also allows some of the individual vectors $\beta \mathrm{i}$ equal to 0 (non causality assumption).

\section{Findings}

Unit Root Tests Results are given in Table 1.

\begin{tabular}{|l|c|c|c|c|}
\hline \multirow{2}{*}{ Unit Root Tests } & \multicolumn{3}{|c|}{ Variables } \\
\cline { 2 - 5 } & \multicolumn{2}{|c|}{ Stock Market } & \multicolumn{2}{c|}{ Unemployment } \\
\cline { 2 - 5 } & Level & First Difference & -0.08063 & $-20.8011^{*}$ \\
\hline Levin, Lin \& Chu t & $-1.36864^{* *}$ & $-28.5338^{*}$ & 48.9566 & $1083.90^{*}$ \\
\hline ADF - Fisher Chi-square & $76.7271^{* *}$ & $925.100^{*}$ & 32.7876 & $1451.47^{*}$ \\
\hline PP - Fisher Chi-square & 34.5195 & $922.250^{*}$ & First Difference \\
\hline
\end{tabular}

Note: *,*, and ***; indicating that the relevant variable is stationary at $1 \%, 5 \%$ and $10 \%$ significance levels, respectively.

Table 1. Unit Root Tests Results

According to the results of stationarity test, both variables were determined to be stationarity in the first difference (I(1)). The first difference of the series was used for Pairwise Dumitrescu Hurlin Panel Causality Tests. Pairwise Dumitrescu Hurlin Panel Causality Tests the results are as follows:

Pairwise Dumitrescu Hurlin Panel Causality Tests Results

\begin{tabular}{lrrr}
\hline \hline Null Hypothesis: & W-Stat. & Zbar-Stat. & Prob. \\
\hline \hline Stock Market does not homogeneously cause Unemployment & 19.1706 & 11.8895 & 0.0000 \\
Unemployment does not homogeneously cause Stock Market & 8.71240 & 0.39229 & 0.6948 \\
\hline \hline
\end{tabular}

According to these results, the null hypothesis of "Stock Market does not homogeneously cause Unemployment" is rejected at the 5\% significance level. Stock Market is the granger cause of Unemployment. The null hypothesis of "Unemployment does not homogeneously cause Stock Market" is not rejected at the 5\% significance level. Unemployment is no the granger cause of Stock Market. There is unidirectional causality between variables. In the long run, the stock market is the determinant of unemployment but not vice versa.

\section{Results}

Unemployment is not the granger cause of Stock Market. There is unidirectional causality between variables. In the long run, the stock market is the determinant of unemployment but not vice versa. The cointegration will tell us the relationship of long run and short among these two while causality indicates either unemployment is causing Stock Market or either Stock Market is causing unemployment or either both variables are causing each other.

\section{References}

- Aktas, E. (2011). Systematic factors, information release and market volatility. Applied Financial Economics, 21(6), 415-420 
- Blanchard, Olivier J., 1981, “Output, the Stock Market, and Interest Rates”, The American Economic Review, Vol. 71, No. 1, 132-143.

- Boyd, J. et al. (2005), The stock market's reaction to un-employment news: Why bad news is usually good for stocks", The Journal of Finance 60, 649-672.

- Boyd, J.H. (2002), "The Stock Market's Reaction to Unemployment News: Why Bad News Is Usually Good for Stocks".

- Brooks, C. and Tsolacos, S. (1999). The impact of economic and financial factors on the UK property performance. Journal of Property Research, 16(2): 139-152.

- Chen, M. Kim, W. and Jeong, K (2005). The impact of macroeconomic and non-macroeconomic forces on hotel stock returns. Hospitality Management, 24: 243-258.

- Chen, N.F., Roll, R., Ross, S.A. (1986), Economic forces and the stock market. Journal of Business, 59(3), 383-403.

- $\quad$ Emerging Sri Lankan Stock Market Sabaragamuwa University Journal, vol 6, no. 1, pp 50-67

- $\quad$ Farsio ,F. \& Fazel,S.(2013), The Stock Market/Unemployment Relationship in USA, China and Japan, International Journal of Economics and Finance; Vol. 5, No. 3

- Francisco J. \& Loredana N.(2016),"US Stock Market And Macroeconomic Factors" ,The Journal of Applied Business Research.

- Gonzalo,J \& Taamout,A(2017) he Reaction of Stock Market Returns to Unemployment, UC3M Working papers Departamento de,

- Gunasekarage, A., Pisedtasalasai, A., Power, D.M. (2004), Macroeconomic influence on the stock market: Evidence from an emerging market in South Asia. Journal of Emerging Market Finance, 3(3), 285-304.

- Humpe, A., and Macmillan, P. (2009). Can macroeconomic variables explain long-term stock market movements? A comparison of the US and Japan. Applied Financial Economics, 19: 111-119.

- Kotha K.K. \& Sahu B. (2016), "Macroeconomic Factors and the Indian Stock Market: Exploring Long and Short Run Relationships”, International Journal of Economics and Financial Issues, 6(3), pp1081-1091.

- Kotha,K.K. \&, Sahu,B. (2016), Macroeconomic Factors and the Indian Stock Market: Exploring Long and Short Run Relationships, International Journal of Economics and Financial Issues

- Liu, M. and Shrestha, K. (2008). Analysis of the long term relationship between Macro-economic variables and the Chinese stock market using heteroscedastic cointegration. Journal of Managerial Finance, 34(11):744-755.

- $\quad$ McQueen, G., Roley, V.V., (1993), Stock prices, news, and business conditions. The Review of Financial Studies 6, 683-707.

- Menike L.M.C.S.(2006), The Effect of Macroeconomic Variables on Stock Prices in

- Mukherjee, T.K., Naka, A. (1995), Dynamic relations between macroeconomic variables and the Japanese stock market: An application of a vector error correction model. Journal of Financial Research, 18(2), 223237.

- Orphanides, Athanasios, 1992, "When Good News Is Bad News: Macroeconomic News and the Stock Market", Working paper, Board of Governors of the Federal Reserve System.

- Orphanides, Athanasios, 1992, "When Good News Is Bad News: Macroeconomic News and the Stock Market", Working paper, Board of Governors of the Federal Reserve System.

- Pal, K., Mittal, R. (2011), Impact of macroeconomic indicators on Indian capital markets. The Journal of Risk Finance, 12(2), 84-97.

- $\quad$ Peiró, A. (1996). Stock prices, production and interest rates: comparison of three European countries with the USA. Empirical Economics, 21: 221-234.

- $\quad$ Rjoub H, Tursoy T, Gunsel N (2009). The effects of macroeconomic factors on stock returns: Istanbul Stock Market. Studies of Economy and Finance, 26(1): 36-45

- $\quad$ Rjoub H, Tursoy T, Gunsel N (2009). The effects of macroeconomic factors on stock returns: Istanbul Stock Market. Studies of Economy and Finance, 26(1): 36-45

- Şerife. Ö. \& Ugur. E. (2012), "Macroeconomic Factors and Stock Returns" International Journal of Academic Research in Business and Social Sciences.

- Şerife. Ö. \& Ugur. E. (2012), "Macroeconomic Factors and Stock Returns" International Journal of Academic Research in Business and Social Sciences. 
- Singh T. et.al., "Macroeconomic factors and stock returns: Evidence from Taiwan" Journal of Economics and International Finance Vol. 2(4), pp.217-227, April 2011

- $\quad$ Singh,T. wt al.(2011) Macroeconomic factors and stock returns: Evidence from Taiwan, Journal of Economics and International Finance Vol. 2(4), pp.217-227

- Tangjitprom, N. (2011), Macroeconomic factors of emerging stock market: The evidence from Thailand. International Journal of Financial Research, 3(2), 105-114.

- Tapa N. at.al.,(2016), "The unemployment-stock market relationship in South Africa: Evidence from symmetric and asymmetric cointegration models", MPRA Paper No. 74101, posted 28 September 2016 07:44 UTC, Online at https://mpra.ub.uni-muenchen.de/74101/

- Wasserfallen, W. (1989). Macroeconomic news and the stock market: Evidence from Europe. Journal of Banking and Finance, 13:613-626.

- Zaheer A. \& Kashif R. (2014), Time Series Analysis of the Relationship between Macroeconomic Factors and the Stock Market Returns in Pakistan, Journal of Yasar University.

Web Links:

- http://www.economywatch.com/international-organizations/organization-of-economic-cooperation-anddevelopment.html

- http://www.oecd.org/about/

- http://www.yourarticlelibrary.com/economics/market/9-most-important-functions-of-stockexchangesecondary-market/8766

- https://blogs.worldbank.org/opendata/new-country-classifications-income-level-2017-2018

- https://study.com/academy/lesson/defining-and-measuring-the-unemployment-rate.html

- https://www.google.com.tr/search?q=how+to+calculate+unemployment+rate\% $\% 3 \mathrm{~A}+$ formula\&oq=how + to + ca lculate+unemployment + rate $\% 3 \mathrm{~A}+$ formula\&aqs $=$ chrome..69i57.21210j0j7\&sourceid $=$ chrome \&ie $=\mathrm{UTF}-8$ 